\title{
A época de Josias na pesquisa recente sobre o Antigo Israel
}

\author{
Orientadora: Prof ${ }^{a}$. Maria de Lourdes Corrêa Lima
}

Pesquisador: José Diógenes Dias Gonçalves

Fonte: Departamento de Teologia

\section{Introdução}

O texto bíblico descreve a reforma política que se seguiu após a descoberta do livro sagrado na restauração do templo, a qual marca o reinado de Josias, (640 - 609 a.C.). A pesquisa histórica/arqueológica colabora para a compreensão destes acontecimentos, trazendo luz para o estudo da extensão e do impacto que teve sobre o extinto Reino do Norte e sobre o Sul. A compreensão destes fatos passa pelo entendimento das circunstâncias desta época, pela geografia, clima e economia da região, bem como sobre a compreensão da sua rede política, que incluía os povos vizinhos, em especial o império neobabilônico, egípcio, e o declínio do império assírio. Os estudos dos aspectos teológicos são enriquecidos com os instrumentos trazidos pelas recentes descobertas históricas e arquelógicas, ao possibilitarem estes uma compreensão mais global do reinado de Josias.

\section{Objetivos}

Apresentar os estudos mais recentes e relevantes sobre a época do rei Josias, sob o aspecto histórico e arqueológico, comparando-os com os relatos bíblicos, possibilitando uma melhor compreensão da história de Judá no contexto político/religioso do Antigo Oriente Próximo e da perspectiva dos textos da Bíblia. 